\title{
PEMBEKALAN PENGETAHUAN DAN KEMANDIRIAN DALAM PERAWATAN KESEHATAN GIGI DAN MULUT MASYARAKAT DESA BALINGBING DAN DESA CIDADAP, KECAMATAN PAGADEN BARAT, SUBANG
}

\author{
Hidayat, W., Nur'aeny, N. dan Wahyuni, I.S. \\ Staf Pengajar Departemen Ilmu Penyakit Mulut Universitas Padjadjaran \\ E-mail: wahyu.hidayat@fkg.unpad.ac.id
}

\begin{abstract}
ABSTRAK
Pembangunan nasional Indonesia tidak akan terlepas dari pembangunan kesehatan masyarakatnya. Upaya peningkatan derajat kesehatan rongga mulut di masyarakat saat ini difokuskan pada usaha promotif dan preventif, sehingga diharapkan usaha menjaga kesehatan gigi akan menjadi kebiasaan yang positif dalam kehidupan bermasyarakat. Saat ini penyebaran fasilitas kesehatan dan tenaga medis di Indonesia masih belum merata. Kurangnya jumlah tenaga medis jika dibandingkan penduduk Indonesia, mendorong pemerintah membentuk kader-kader kesehatan untuk membantu usaha promotif dan preventif di bidang kesehatan. Atas dasar demikian maka perlu dibentuk kader-kader kesehatan gigi yang merupakan bagian dari kesehatan secara umum. Target dan sasaran program KKNM PPMD ini adalah pembentukan kader kesehatan gigi yaitu mahasiswa, kader PKK dan Posyandu serta anak-anak sekolah dasar. Selain kaderisasi juga dilakukan bakti sosial untuk mengetahui kondisi kesehatan rongga mulut di lokasi KKNM saat ini. Sekitar kurang lebih 30 orang kader PKK dan Posyandu diberikan materi pemeliharaan kesehatan ronga mulut yang diberikan oleh mahasiswa dibawah supervisi dosen pembimbing. Hasil pemeriksaan mukosa mulut diperoleh data lesi mulut yang sering ditemukan adalah coated tongue dengan jumlah 76 orang anak. Keberhasilan kaderisasi didasarkan pada hasil pretest dan posttest. Peningkatan pengetahuan kesehatan gigi pada kader diharapkan dapat mentransfer pengetahuannya untuk mencapai peningkatan kualitas hidup masyarakat.
\end{abstract}

Kata Kunci: kesehatan rongga mulut, kader, lesi mulut

\section{ABSTRACT}

Indonesian development can not be separated from the public health development. The improvement of community oral health status is currently focused on promotive and preventive, with the goal to make good health care as a positive habit in the society. Currently the spread of medical and health facilities in Indonesia is still not well distributed and the amount is less than the population. The government also concerned to establish a health care cadre to helps the promotion and prevention activity in the community. So it is necessary to set up dental health cadre as part of general health care. The goals of this KKNM PPMD programme is to create some volunteers for dental health care, including dental students, cadres of PKK and Posyandu, and elementary school children. This programme also provide some social service in order to know the oral health condition in target population. Approximately less than 30 "PKK" and "posyandu" cadres got topics about oral health maintanance given by dental students under supervision of lecturers. From oral examination showed coated tongue as most common oral lesion with the number of 76 children.The success of making cadres based on the good results of the pretest and post test. This cadres are expected can transfer knowledge to improve the quality of life in community.

Key words : Oral health, cadre, oral lesion

\section{PENDAHULUAN}

Dalam upaya meningkatkan kesehatan gigi dan mulut di Indonesia dirasakan penting untuk dilakukan mengingat masih tinggi indeks penyakit gigi dan mulut pada masyarakat Indonesia, sehingga dengan demikian segala upaya untuk meningkatkan kesehatan mulut dan gigi merupakan sebuah cara untuk meningkatkan kualitas hidup masyarakat. Penyakit gigi dan mulut dipengaruhi oleh lingkungan, kebiasaan dan sarana pelayanan kesehatan gigi, jika semuanya dapat diperbaiki dan di tingkatkan maka target kesehatan gigi dan mulut akan dapat tercapai dan kuallitas hidupun akan meningkat. Menurut penelitian Setiawan melaporkan sekitar 88,3\% status kebersihan gigi dan mulutnya masuk kedalam kategori tidak bersih, sedangkan mayoritas penyakit gigi dan mulut yang bayak dialami penduduk di Indonesia pada umumnya disebabkan oleh kondisi mulut yang tidak bersih.

Masalah kesehatan gigi dan mulut merupakan bagian dari kesehatan masyarakat seutuhnya, termasuk bagi masyarakat di Desa Balingbing dan Desa Cidadap, Kecamatan Pagaden Barat, Kabupaten Subang. Kedua desa tersebut merupakan daerah yang jauh dari pusat pelayanan kesehatan gigi dan mulut. Puskesmas Kecamatan Pagaden Barat yang menaungi wilayah kedua 
desa tersebut tidak memiliki dokter gigi namun hanya terdapat seorang perawat gigi untuk melayani kesehatan gigi dan mulut masyarakat. Dikarenakan keterbatasan tenaga medis dan fasilitas tenaga kesehatan yang masih kurang membuat pemberdayaan potensi masyarakat turut serta dilibatkan dalam usaha promotif dan preventif tersebut. Potensi masyarakat yang dapat turut serta dilibatkan dalam proses promotif dan preventif yaitu kader PKK dan posyandu. Sehingga pemberian materi menjaga kesehatan gigi dan mulut pada kader masyarakat tersebut diharapkan dapat membentuk kebiasaan atau perilaku menjaga kesehatan gigi dan mulut yang benar dan dimulai sejak usia dini terutama pada anak-anak sekolah dasar.

Masalah kesehatan gigi dan mulut yang sering ditemui berupa gigi berlubang, radang gusi, sariawan dan lain lain. KKNM-PPMD Integratif diharapkan dapat membantu memberikan jalan keluar atas masalah tersebut dengan upaya memberikan pembekalan pengetahuan dan kemandirian dalam perawatan kesehatan gigi dan mulut masyarakat desa dan anak sekolah sehari hari.

Masyarakat/ kader yang menjadi target utama dalam program ini adalah kader PKK dan Posyandu, sebelumnya telah diberikan penyuluhan dan pelatihan oleh mahasiswa yang mengikuti program KKNM yang dilatih sebagai trainer dalam Pelatihan Pelatih Kader Kesehatan Gigi dan Mulut (Training of trainer / TOT), sehingga mahasiswa tersebut mampu memberikan pelatihan kepada kader kesehatan masyarakat/sekolah di bawah bimbingan dosen supervisor. Ilmu yang diberikan selama pelatihan juga dapat menjadi bekal mahasiswa dan masyarakat dalam merawat kesehatan gigi dan mulut pribadi sehari-hari.

Pembekalan pengetahuan untuk perawatan kesehatan gigi dan mulut masyarakat sehari hari diberikan dalam bentuk pelatihan sehingga diharapkan dapat mencapai kemandirian masyarakat dalam melakukan perawatan kesehatan gigi dan mulut sehari hari. Masyarakat yang mampu mandiri dalam melakukan perawatan kesehatan gigi dan mulut sehari hari akan meningkatkan derajat kesehatan gigi dan mulut serta kesehatan tubuh secara utuh dan benar melaui upaya promotif dan preventif.

Upaya promotif dan preventif yang diberikan adalah ilmu mengenai perawatan kesehatan gigi dan mulut sehari-hari sehingga menjadi bekal mahasiswa dalam merawat kesehatan pribadi sehari-hari kemudian mentransfernya kepada kader PKK dan Posyandu selaku bagian dari masyarakat.

Hasil pelatihan masyarakat/ Kader Posyandu dan Kader/ Guru UKS diharapkan masyarakat dapat memi- liki pengetahuan mengenai perawatan kesehatan gigi dan mulut sehari-hari, Kader kesehatan dapat membina masyarakat di lingkungannya untuk melakukan perawatan kesehatan gigi dan mulut sehari-hari dengan menggunakan media penyuluhan yang dibuat oleh mahasiswa KKNM, selain itu masyarakat dan anak sekolah mampu melakukan perawatan kesehatan gigi dan mulut sehari-hari secara mandiri, Masyarakat mendapatkan pemeriksaan dan konsultasi gigi dan mulut gratis dalam kegiatan bakti sosial yang dilakukan oleh dosen.

Manfaat jangka panjang (outcome) adalah: masyarakat diharapkan dapat mencapai kemandirian dalam melakukan perawatan kesehatan gigi dan mulut sehari hari, serta meningkatkan derajat kesehatan gigi dan mulut serta kesehatan tubuh secara benar, dan masyarakat juga mendapatkan pemeriksaan dan konsultasi gigi dan mulut gratis dalam kegiatan bakti sosial yang dilakukan oleh dosen.

\section{METODE}

Kegiatan Pelatihan / Work-Shop Training of trainer (TOT) dilakukan dalam beberapa bentuk kegiatan yaitu pemberian dan pengayaan materi, demonstrasi partisipatif, dan pembuatan media untuk materi penyuluhan. Kegiatan lainnya yaitu kegiatan Pelatihan Kader akan diadakan dalam bentuk pendampingan bagi trainer (mahasiswa KKNM) oleh dosen, Kader PKK dan posyandu, kader kesehatan, guru SD, pelajar SD dan SMP. Kegiatan terakhir yaitu bakti social dilaksanakan dengan melibatkan partisipasi aktif dosen dalam melakukan pemeriksaan kesehatan gigi dan mulut serta memberikan konsultasi.

\section{HASIL DAN PEMBAHASAN}

Rangkaian kegiatan KKNM PPMD 2016 yang sudah dilakukan adalah kegiatan pelatihan TOT (Training of trainer) yang ditujukan kepada mahasiswa KKNM yang kemudian akan melakukan pelatihan dan pembekalan kepada masyarakat dalam hal ini adalah kader PKK dan posyandu dibawah supervisi dosen, sehingga diharapkan informasi yang didapat oleh kader PKK dan posyandu akan dapat disampaikan kepada masyarakat umum dengan baik dan benar. Penyampaian materi kepada masyarakat akan menggunakan media model berupa kalender, poster dan model gigi serta dibantu dengan presentasi dalam bentuk powerpoint. 
Tabel 1. Indikator pelaksanaan program

\begin{tabular}{|c|c|c|c|}
\hline No & Indikator & $\begin{array}{c}\text { Base Line } \\
\text { (sebelum kegiatan) }\end{array}$ & $\underset{\text { Kegiatan }}{\text { Pencapaian }}$ Setelah \\
\hline 1. & $\begin{array}{l}\text { Kegiatan Pelatihan Pelatih Kader Kesehatan (TOT) Gigi dan Mulut: } \\
\text { - Tingkat pengetahuan mahasiswa mengenai perawatan kesehatan gigi } \\
\text { dan mulut } \\
\text { - Keterampilan mahasiswa memberikan penyuluhan mengenai } \\
\text { perawatan kesehatan gigi dan mulut } \\
\text { - Alat bantu/media penyuluhan perawatan kesehatan gigi dan mulut. }\end{array}$ & $\begin{array}{l}\text { - Kurang. } \\
\text { - Belum mampu } \\
\text { - Belum tersedia }\end{array}$ & $\begin{array}{l}\text { - Lebih baik. } \\
\text { - Mampu. } \\
\text { - Tersedia }\end{array}$ \\
\hline 2. & $\begin{array}{l}\text { Kegiatan Pelatihan Kader Kesehatan Gigi dan Mulut: } \\
\text { - Tingkat pengetahuan kader mengenai perawatan kesehatan gigi dan } \\
\text { mulut. } \\
\text { - Keterampilan kader memberikan penyuluhan mengenai perawatan } \\
\text { kesehatan gigi dan mulut. } \\
\text { - Alat bantu/media penyuluhan perawatan kesehatan gigi dan mulut. }\end{array}$ & $\begin{array}{l}\text { - Kurang. } \\
\text {-Belum mampu } \\
\text { - Belum tersedia }\end{array}$ & $\begin{array}{l}\text { - Lebih baik. } \\
\text { - Mampu. } \\
\text { - Tersedia dan kader } \\
\text { mampu memanfaatkan. }\end{array}$ \\
\hline 3. & $\begin{array}{l}\text { Kegiatan Bakti Sosial Kesehatan Gigi dan Mulut: } \\
\text { - Tingkat pengetahuan masyarakat mengenai perawatan kesehatan gigi } \\
\text { dan mulut. } \\
\text { - Target pelayanan }\end{array}$ & - Kurang. & $\begin{array}{l}\text { - Lebih baik. } \\
30 \text { orang/desa. }\end{array}$ \\
\hline
\end{tabular}

Tabel 2. Capaian kegiatan KKNM PPMD

\begin{tabular}{|c|c|c|}
\hline No & Kegiatan & Pencapaian Setelah Kegiatan \\
\hline 1. & $\begin{array}{l}\text { Pelatihan Pelatih Kader Kesehatan (TOT) Gigi dan } \\
\text { Mulut }\end{array}$ & $\begin{array}{l}\text { - Tingkat pengetahuan mahasiswa menjadi lebih baik lagi terutama } \\
\text { mengenai perawatan kesehatan gigi dan mulut } \\
\text { - Mahasiswa mampu memberikan penyuluhan mengenai perawatan } \\
\text { kesehatan gigi dan mulut } \\
\text { - Tersedianya alat bantu/media penyuluhan perawatan kesehatan gigi } \\
\text { dan mulut }\end{array}$ \\
\hline 2. & Pelatihan Kader Kesehatan Gigi dan Mulut & $\begin{array}{l}\text { - Tingkat pengetahuan kader menjadi lebih baik lagi terutama } \\
\text { mengenai perawatan kesehatan gigi dan mulut } \\
\text { - Kader mampu memberikan penyuluhan mengenai perawatan } \\
\text { kesehatan gigi dan mulut. } \\
\text { - Tersedia alat bantu/media penyuluhan perawatan kesehatan gigi dan } \\
\text { mulut. } \\
\text { dan kader mampu memanfaatkannya }\end{array}$ \\
\hline 3. & Bakti Sosial Kesehatan Gigi dan Mulut & $\begin{array}{l}\text { - Meningkatnya tingkat pengetahuan masyarakat mengenai perawatan } \\
\text { kesehatan gigi dan mulut }\end{array}$ \\
\hline
\end{tabular}

Kegiatan pembekalan dan pemberian materi kesehatan gigi tidak hanya diberikan pada kader PKK dan Posyandu juga diberikan pada murid-murid sekolah dasar di sekitar desa, kemudian dilanjutkan dengan sesi sikat gigi bersama. Kemudian pada hari yang telah disepakati akan dilakukan kegiatan baksos berupa pemeriksaan kesehatan mulut anak sekolah dasar dan sekolah menengah pertama di sekitar desa. Hasil pemeriksaan tersebut akan menjadi data sejauh mana kepedulian masyarakat terhadap kesehatan mulutnya selain sebagai data yang menggambarkan kondisi kesehatan rongga mulutnya secara keseluruhan.

Selain indikator keberhasilan kaderisasi materi penyuluhan kesehatan gigi dan mulut, juga dilakukan survey kesehatan gigi dan mulut pada anak sekolah dasar dan sekolah menengah sebagai gambaran penilaian kondisi kesehatan rongga mulutnya secara umum. Pada tabel dibawah ini memperlihatkan mengenai deskripsi kelainan rongga mulut yang ditemukan di sekolah dasar dan menengah di Desa Cidadap dan Balingbing.
Tabel 3. Deskripsi lesi oral

\begin{tabular}{|c|c|c|c|c|}
\hline No & $\begin{array}{c}\text { Manifestasi } \\
\text { oral }\end{array}$ & Pria & Wanita & Keterangan \\
\hline 1 & Coated tongue & 44 orang & 32 orang & 76 orang \\
\hline 2 & Fissure tongue & - & - & - \\
\hline 3 & $\begin{array}{l}\text { Angular } \\
\text { cheilitis }\end{array}$ & 3 orang & 1 orang & 4 orang \\
\hline 4 & $\begin{array}{l}\text { Stomatitis } \\
\text { aphthous }\end{array}$ & 4 orang & 5 orang & 9 orang \\
\hline 5 & $\begin{array}{l}\text { Geographic } \\
\text { tongue }\end{array}$ & 3 orang & 2 orang & 5 orang \\
\hline \multirow[t]{2}{*}{6} & Fibroma & 1 orang & - & 1 orang. \\
\hline & Jumlah & 55 & 40 & 95 \\
\hline
\end{tabular}

\section{HASIL DAN PEMBAHASAN}

Kegiatan TOT kepada mahasiswa KKNM dilakukan oleh dosen pembimbing dibantu oleh anggota tim KKNM PPMD. Kegiatan berlangsung selama 3 kali pertemuan untuk Desa Balingbing dan Desa Cidadap. Sebelum dilakukan penyampaian materi, terlebih dahulu dilakukan 
kuisioner untuk mengetahui sejauh mana pengetahuan mahasiswa mengenai kesehatan gigi, dari hasil kuisioner diketahui pengetahuan mengenai kesehatan gigi pada mahasiswa KKNM masih minim dan kurang benar. Hasil kuisioner pretest dapat menjadi bahan evaluasi dalam pemberian pengayaan materi kesehatan gigi yang diberikan. Setelah diberikan materi TOT selama 3 kali pertemuan, akhirnya mahasiswa mengerti mengenai pemeliharaan kesehatan gigi yang baik dan benar.

Pelatihan kader PKK dan Posyandu diberikan di bawah supervisi dosen pembimbing, dalam pemberian materi mahasiswa dibantu dengan model gigi, poster dan kalender gigi serta presentasi dengan menggunakan perangkat media infokus agar mudah dipahami oleh kader PKK dan Posyandu serta lebih menarik dan tidak membosankan. Pada kegiatan ini juga dilakukan pretest dan post-test kepada kader PKK dan Posyandu sebagai indikator keberhasilan pemberian materi kesehatan gigi. Pada saat pelaksanakan pembekalan materi disediakan sesi tanya jawab yang ternyata banyak kader yang menanyakan berbagai masalah berkaitan dengan kesehatan gigi dan perawatannya. Melalui pendekatan dialog interaktif antara masyarakat dengan pelatih ternyata dapat menjawab semua permasalahan yang berhubungan dengan kesehatan gigi sehingga masyarakat menjadi lebih memahami.

Dari hasil survei dalam bakti sosial yang diadakan pada 3 sekolah, diperoleh jumlah terbanyak lesi oral yang ditemukan adalah lesi coated tongue, lesi coated berhubungan dengan beberapa faktor diantaranya diet lunak, penggunaan antibiotik, stress, anemia dan kebiasaan tidak menyikat lidah. Melalui pemberian materi tentang cara menyikat gigi dan mulut secara benar diharapkan kebiasaan menyikat gigi tidak hanya terfokus pada geligi saja tetapi juga pada jaringan lunaknya yaitu lidah. Lesi angular cheilitis juga ditemukan pada beberapa anak. Angular cheilitis atau perleche merupakan lesi berbentuk ulser yang merupakan salah satu tanda khas manifestasi anemia, kandidiasis atau infeksi bakteri, terletak di sudut mulut serta dapat disertai rasa nyeri. Defisiensi nutrisi vitamin B atau zat besi serta diet karbohidrat dapat memicu timbulnya angular cheilitis. Lesi lainnya yang ditemukan adalah stomatitis, merupakan salah satu contoh bentuk lesi ulseratif, yang disebabkan oleh infeksi bakteri, infeksi virus, faktor genetik, kelainan hematologi/anemia, kelainan imun, dan faktor lokal seperti trauma. Lesi lainnya yang ditemukan pada pemeriksaan yaitu geographic tongue, beberapa laporan menyebutkan kondisi tersebut berhubungan dengan kelainan sitemik seperti psikologis, psoriasis, reiters syndrome, anemia, gangguan pencernaan, defisiensi nutrisi, candidiasis, lichen planus, ganguan hormon, dan alergi. Biasanya tidak disertai rasa nyeri tetapi tidak tertutup kemungkinan disertai nyeri. ${ }^{4,5,6}$

\section{SIMPULAN}

Pemberdayaan potensi masyarakat melalui kader PKK dan Posyandu untuk menjadi kader kesehatan gigi dan mulut dapat menjadi salah satu upaya promotif dan preventif yang efektif, serta pola menjaga kesehatan gigi mulut dapat secara efektif tersampaikan kepada masyarakat dan menjadikannya sebagai sebuah kebiasaan sehingga diharapkan jika dilakukan pemeriksaan kesehatan kembali di lokasi yang sama akan diperoleh data angka kesehatan gigi yang meningkat baik.

\section{DAFTAR PUSTAKA}

Armasastra, B. 2000. Masalah kesehatan gigi dan mulut lansia di desa Lengkong Gudang dan Serpong serta saran penanggulangannya melalui peran kader kesehtan desa. Jurnal Kedokteran Gigi UI. 7:311-7.

Alhamda S. 2011. Status Kebersihan Gigi dan Mulut dengan Status Karies Gigi ( Kajian pada Murid Kelompok Umur 12 Tahun di Sekolah Dasar Negeri Kota Bukittinggi). Berita Kedokteran Masyarakat. 27(2):108-15.

Tarçın BG. 2011. Oral Candidosis: Aetiology, Clinical Manifestations, Diagnosis and Management. Journal of Marmara University Institute of Heallth Science. 1 (2):140-8.

Greenberg Martin MG. 2003. Burket's oral medicine oral diagnostic and treatment. tenth. $\mathrm{BC}$ Decker Inc; p. 429.

Kementrian, RI 2012. Buku Panduan Pelatihan Kader Kesehatan Gigi Dan Mulut Dl Masyarakat.

Moreno Chulilla JA. 2012. Classification of anemia for gastroenterologists. World Journal of Gastroenterology [Internet]. 2009 [cited 2012 Nov 5];15(37):4627. Available from: http://www. wjgnet.com/1007-9327/15/4627.asp 